\title{
Comparative pollen morphological analysis in the subgenera Passiflora and Decaloba
}

\author{
TALIANE L. SOARES ${ }^{1}$, ONILDO N. JESUS $^{1 *}$, EVERTON H. SOUZA ${ }^{1,2}$, \\ MÔNICA L. ROSSI ${ }^{3}$ and EDER J. OLIVEIRA ${ }^{1}$
}

\begin{abstract}
${ }^{1}$ Embrapa Mandioca e Fruticultura, Rua Embrapa, s/n, Chapadinha, C.P. 007, 44380-000 Cruz das Almas, BA, Brazil ${ }^{2}$ Universidade Federal do Recôncavo da Bahia, Campus de Cruz das Almas, 44380-000 Cruz das Almas, BA, Brazil

${ }^{3}$ Universidade de São Paulo, CENA/USP, Av. Centenário, 303, São Dimas, 13400-970 Piracicaba, SP, Brazil
\end{abstract}

Manuscript received on May 3, 2017; accepted for publication on June 8, 2017

\begin{abstract}
The genus Passiflora is the most diversified of the Passifloraceae, and its palynology presents wide morphological variability. The objective of the study was to evaluate the pollen morphology of 18 Passiflora species in order to identify informative pollinic characteristics to contribute to the taxonomic classification of the genus. The morphology of the pollen grains and the exine structure were investigated using light microscopy and scanning electron microscopy. Differences in the pollen morphology were found in the studied species, mainly in terms of shape, pollen aperture and ornamentation pattern of the exine. Most of the species belonging to the subgenus Passiflora presented ornamented 6-syncolpate pollen grains with an oblate-spheroidal shape and an exine with large lumens. In the subgenus Decaloba the pollen grains were 6-colporate, 12-colpate and 12-colporate, with subprolate to prolate-spheroidal shape, as well as an exine with smaller lumen size and few ornamented. The pollen morphology of the species of the subgenera Passiflora and Decaloba has shown palynological characteristics that have specific diagnostic value, thus allowing a better understanding of the taxonomy of the genus Passiflora.
\end{abstract}

Key words: Passifloraceae, pollen grains, scanning electron microscopy, exine, morphological characterization.

\section{INTRODUCTION}

The genus Passiflora L. is the most representative of the Passifloraceae, with approximately 576 species (Ocampo and D'Eeckenbrugge 2017) from the tropical and temperate regions of South America (Krosnick et al. 2013). Brazil has approximately 150 species, and most of them are endemic in the

Correspondence to: Onildo Nunes de Jesus

E-mail: onildo.nunes@embrapa.br

* Contribution to the centenary of the Brazilian Academy of Sciences. country (Bernacci et al. 2015). This genus was initially divided into 23 subgenera according to Killip (1938) and subsequently reduced to only five: Astrophea (DC.) Mast., Deidamioides (Harms) Killip, Decaloba (DC.) Rchb., Tetrapathea (DC.) Reichb. and Passiflora L. (Feuillet and MacDougal 2003, Krosnick et al. 2009). However, the two largest subgenera are Passiflora ( 250 species) and Decaloba ( 230 species) (Porter-Utley 2014).

Due to the great morphological diversity, pollen grains have been used for taxonomic purposes, assisting in the morphological characterization 
and identification of some species to generate phylogenetic information that more accurately expresses the origin and evolution of the organisms (Judd et al. 2007). The pollen characteristics are fundamental for taxonomic classification because the pollen grains present the shape, size, color and ornamentation of the exine defined for each species, genus and family (Mert 2010, Fazal et al. 2013, Silvério and Mariath 2014, Mezzonato-Pires et al. 2015a, Silva et al. 2016).

Passifloraceae is very interesting from the palynological point of view because the pollen grains present great phenotypic variability for several characteristics, some that have still not been explored according to systematic and phylogenetic aspects (Dettke and Santos 2009). Mohl (1834) and Fritzsche (1837) were the first researchers to use the pollen morphology of Passiflora species for taxonomic purposes, highlighting the shape and ornamentation as good taxonomic characteristics. Based on these studies, some other research have focused on palynology in the differentiation of Passiflora and/or species (Amela Garcia et al. 2002, Milward-de-Azevedo et al. 2010, 2014a, Gabarayeva et al. 2013, Mezzonato-Pires et al. 2015a,b). However, few studies simultaneously analyzed different subgenera of the Passifloraceae (Mezzonato-Pires et al. 2015b). Therefore, the objective of this work was to evaluate the pollen morphology of eighteen Passiflora species in order to identify informative pollinic characteristics to contribute to the taxonomic classification of the genus.

\section{MATERIALS AND METHODS}

\section{PLANT MATERIAL}

Eighteen Passiflora species, represented for two subgenera according the classification of Feuillet and MacDougal (2003) were analyzed (Table I; Figure 1): Passiflora alata Curtis. (BGP004, HURB-20749), P. gibertii N. E. Br. (BGP-
008, HURB-20753), P. edulis Sims f. flavicarpa Degener (BGP-038, HURB-20754), P. edmundoi Sacco (BGP-046, HURB-20745), P. tenuifila Killip (BGP-105, HURB-20750), P. morifolia Mast. (BGP-107, HURB-20740), P. galbana Mast. (BGP109, HURB-20743), P. muchronata Sessé \& Moc. (BGP-114, HURB-20848), P. rubra L. (BGP-125, HURB-20752), P. suberosa L. (BGP-152, HURB20742), P. foetida L. (BGP-153, HURB-20741), P. malacophylla Mast. (BGP-170, HURB-20747), P. racemosa Brot. (BGP-172, HURB-20744), $P$. setacea L. (BGP-237, HURB-20755), P. cincinnata Mast. (BGP-312, HURB-20746), P. maliformis L. (BGP-379, HURB-20756), P. subrotunda L. (BGP394, HURB-20751) and P. coccinea Aubl. (BGP408, HURB-20748). These species belonging to the Active Germplasm Bank of Passion fruit (AGP) from Embrapa Mandioca e Fruticultura located in Cruz das Almas, Bahia Brazil (12 ${ }^{\circ} 48^{\prime} 38^{\prime \prime} \mathrm{S}$ and $39^{\circ} 06^{\prime} 26^{\prime}$ 'O; $\left.220 \mathrm{~m}\right)$. Specimen of each taxon were deposited in the HURB herbarium (Universidade Federal do Recôncavo da Bahia).

In this study, we followed the two taxonomic treatments of genus Passiflora proposed by Killip 1938 (with emends by Escobar 1988, 1989, 1994; and MacDougal 1994) by Feuillet and MacDougal (2003) as a point of comparison and discussion of our data. Most of these species were preserved in greenhouses, except for $P$. setacea, $P$. maliformis and $P$. alata, which were preserved under field conditions. Each Passiflora species was represented by one accession identified by the BGP code.

\section{MORPHOPOLLINIC CHARACTERIZATION}

For the morphopollinic characterization, the pollen grains were fixed in modified Karnovsky's solution (Karnovsky 1965) [glutaraldehyde (2\%), paraformaldehyde $(2 \%), \mathrm{CaCl}_{2}(0.001 \mathrm{M})$, sodium cacodylate buffer $(0.05 \mathrm{M}), \mathrm{pH}$ 7.2] for 48 hours and then dehydrated in increasing concentrations of ethanol (35-100\%) for 20 minutes each. The 
TABLE I

List of 18 Passiflora species of the genus Passiflora L. used in this study.

\begin{tabular}{|c|c|c|c|c|c|c|}
\hline Access & Species & Subgenus & $\begin{array}{c}\text { Supersection/section } \\
\text { or series }\end{array}$ & Pollinator & $2 n$ & $\begin{array}{l}\text { Compat.* } \\
\text { Systematic }\end{array}$ \\
\hline BGP-004 & P. alata Curtis & Passiflora L. & $\begin{array}{l}\text { Laurifolia (Cervi) Feuillet \& } \\
\text { MacDougal/ Quadrangulares } \\
\text { Feuillet \& MacDougal }\end{array}$ & Bees & 18 & SI \\
\hline BGP-008 & $\begin{array}{l}\text { P. gibertii N. } \\
\text { E. Br. }\end{array}$ & Passiflora L. & $\begin{array}{c}\text { Stipulata } \text { Feuillet \& } \\
\text { MacDougal/ } \\
\text { Granadillastrum Triana \& } \\
\text { Planch. }\end{array}$ & Bees & 18 & SI \\
\hline BGP-038 & $\begin{array}{l}\text { P. edulis Sims f. } \\
\text { flavicarpa Deg. }\end{array}$ & Passiflora L. & Passiflora/Passiflora & Bees & 18 & SI \\
\hline BGP-046 & $\begin{array}{l}\text { P. edmundoi } \\
\text { Sacco }\end{array}$ & Passiflora L. & $\begin{array}{c}\text { Stipulata Feuillet \& } \\
\text { MacDougal /Kermesinae } \\
\text { Killip ex Cervi }\end{array}$ & Hummingbirds & 18 & SI \\
\hline BGP-105 & P. tenuifila Killip & Passiflora L. & Passiflora/Passiflora & Bees & 18 & $\mathrm{SC}$ \\
\hline BGP-107 & $\begin{array}{l}\text { P. morifolia } \\
\text { Mast. }\end{array}$ & $\begin{array}{l}\text { Decaloba } \\
\text { D.C Rchb. }\end{array}$ & $\begin{array}{c}\text { Bryonioides (Harms) } \\
\text { MacDougal \& Feuillet/ } \\
\text { Cieca (Medic.) MacDougal \& } \\
\text { Feuillet }\end{array}$ & Wasps & 12 & $\mathrm{SC}$ \\
\hline BGP-109 & P. galbana Mast. & Passiflora L. & $\begin{array}{c}\text { Passiflora/Simplicifoliae } \\
\text { Harms) Killip }\end{array}$ & Bats & 18 & SI \\
\hline BGP-114 & $\begin{array}{l}\text { P. muchronata } \\
\text { Sessé \& Moc. }\end{array}$ & Passiflora L. & $\begin{array}{l}\text { Passiflora/Simplicifoliae } \\
\text { Harms) Killip }\end{array}$ & Bats & 18 & SI \\
\hline BGP-125 & P. rubra $\mathrm{L}$. & $\begin{array}{l}\text { Decaloba } \\
\text { D.C Rchb. }\end{array}$ & $\begin{array}{c}\text { Decaloba (DC.) MacDougal \& } \\
\text { Feuillet/ } \\
\text { Xerogona (Raf.) Killip }\end{array}$ & Wasps & 12 & $\mathrm{SC}$ \\
\hline BGP-152 & P. suberosa L. & $\begin{array}{l}\text { Decaloba } \\
\text { D.C Rchb. }\end{array}$ & $\begin{array}{c}\text { Decaloba (DC.) MacDougal \& } \\
\text { Feuillet/ } \\
\text { Cieca (Medic.) MacDougal \& } \\
\text { Feuillet }\end{array}$ & Wasps & 24 & $\mathrm{SC}$ \\
\hline BGP-153 & P. foetida L. & Passiflora L. & $\begin{array}{c}\text { Stipulata Feuillet \& } \\
\text { MacDougal/Dysosmia DC. }\end{array}$ & Bees & $\begin{array}{l}18,20 \\
22\end{array}$ & $\mathrm{SC}$ \\
\hline BGP-170 & $\begin{array}{c}\text { P. malacophylla } \\
\text { Mast. }\end{array}$ & Passiflora $\mathrm{L}$. & Passiflora/Serratifoliae & Bees & 18 & SI \\
\hline BGP-172 & $\begin{array}{l}\text { P. racemosa } \\
\text { Brot. }\end{array}$ & Passiflora L. & $\begin{array}{l}\text { Stipulata Feuillet \& } \\
\text { MacDougal/ } \\
\text { Calopathanthus Harms }\end{array}$ & Bees & 18 & SI \\
\hline BGP-237 & P. setacea L. & Passiflora L. & $\begin{array}{c}\text { Passiflora/Setaceae } \\
\text { Killip ex Cervi }\end{array}$ & Bats & 18 & SI \\
\hline BGP-312 & $\begin{array}{l}\text { P. cincinnata } \\
\text { Mast. }\end{array}$ & Passiflora L. & Passiflora/Passiflora & Bees & 18 & SI \\
\hline BGP-379 & P. maliformis $\mathrm{L}$. & Passiflora L. & $\begin{array}{c}\text { Laurifolia (Cervi) Feuillet \& } \\
\text { MacDougal/Laurifoliae Killip } \\
\text { ex Cervi }\end{array}$ & Bees & 18 & SI \\
\hline BGP-394 & P. subrotunda L. & Passiflora L. & Passiflora/Simplicifoliae & Bees & 18 & SI \\
\hline BGP-408 & P. coccinea Aubl & Passiflora L. & $\begin{array}{l}\text { Coccinea Feuillet \& } \\
\text { MacDougal }\end{array}$ & Hummingbirds & 18 & SI \\
\hline
\end{tabular}

Taxonomic classification, their pollinators, diploid numbers, compatibility systematic, according to Feuillet and MacDougal (2003), Melo et al. (2001), Melo and Guerra (2003), Soares et al. (2015). *SI = self-incompatible, SC = self-compatible. 

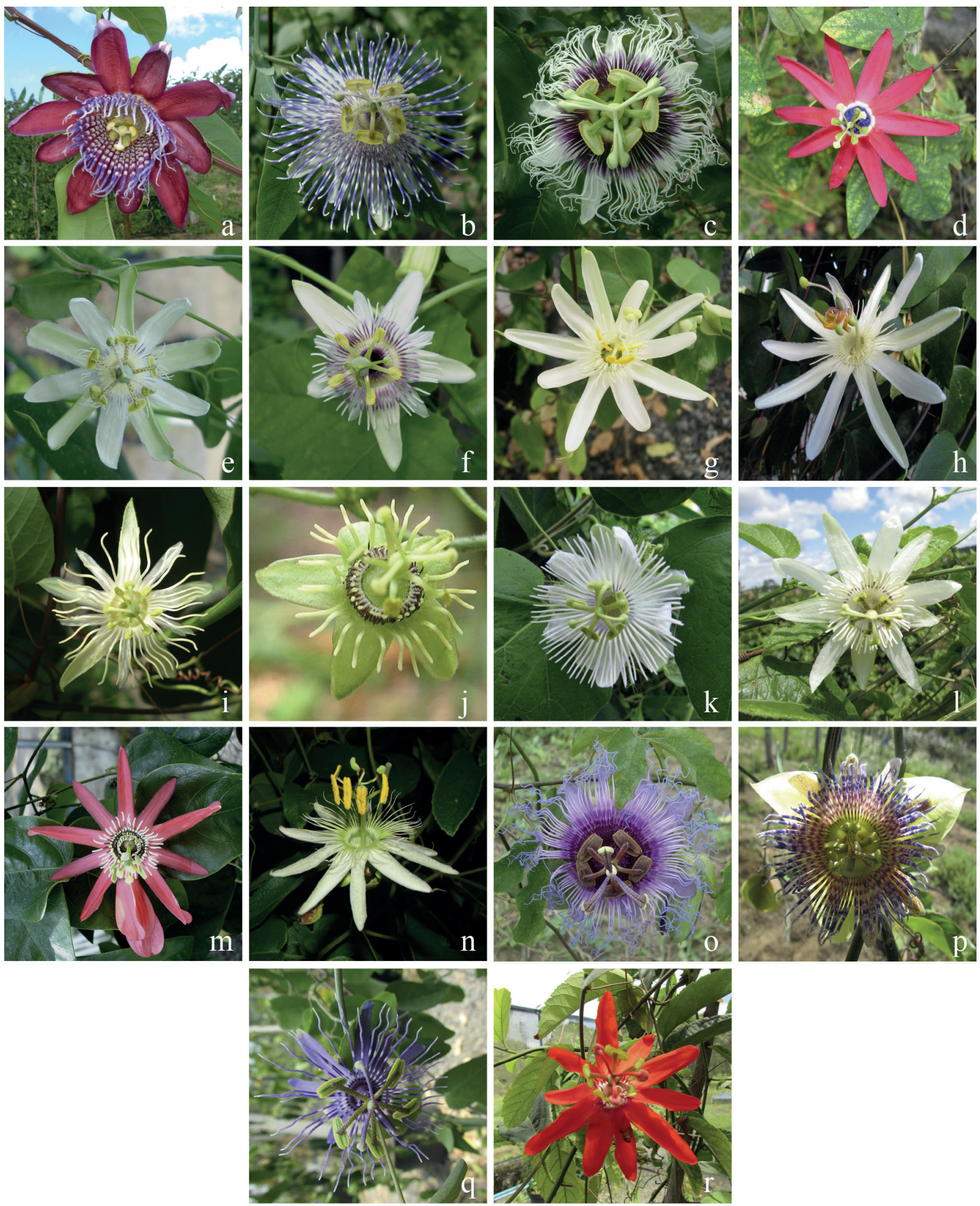

Figure 1 - General view of flowers of 18 Passiflora species used in this study: a) P. alata, b) P. gibertii, c) P. edulis f. flavicarpa, d) $P$. edmundoi, e) $P$. tenuifila, f) $P$. morifolia, g) $P$. galbana, h) $P$. muchronata, i) $P$. rubra, j) $P$. suberosa, k) $P$. foetida, l) $P$. malacophylla, m) $P$. racemosa, $\mathbf{n}) P$. setacea, o) $P$. cincinnata, $\mathbf{p})$ P. maliformis, q) $P$. subrotunda and $\mathbf{r}) P$. coccinea . 
samples were dried out in hexamethyldisilazane, and the dried samples were then mounted on metallic supports (stubs), metallized with gold for 180 s using a sputter coater (MED 010, Balzers Union, Balzers, Liechtenstein). The images were obtained using the LEO 435 VP variable pressure scanning electron microscope (Carl Zeiss, Jena, Germany), at $20 \mathrm{kv}$.

The pollen grains were submitted to weak lactic acetolysis (ACLAC 40), according to Raynal and Raynal (1979), and the assessments were obtained using the Image J 1.46r program (Rasband 1997-2016). Quantitative characters, polar (PD) and equatorial (ED) diameters of 25 pollen grains per species were measured $(\mu \mathrm{m})$ at random in equatorial view. We also computed the shape (PD/ED ratio), number and aperture type, and exine ornamentation of the pollen grains. The pollen grains were characterized according to the nomenclature described by Punt et al. (2007) and Hesse et al. (2009), and for the general description of the pollen openings, we adopted the definition of Presting (1965).

The pollen grains were photographed digitally using the Olympus microscope (DM1000; Leica Microsystems, Wetzlar, Germany) coupled with a Sony (Sony, Tokyo, Japan) video camera and a microcomputer using Image Pro-plus Software version 3.0 for Windows (Media Cybernetics, Inc., Bethesda, MD, USA).

\section{DATA ANALYSIS}

Qualitative (aperture and shape) and quantitative data were submitted to multivariate analysis to determine genetic distance using the Gower distance (1971). The validation of the clusters was determined by the cophenetic correlation (cc) (Sokal and Rohlf 1962). The R (R Development Core Team 2015) program was used to obtain the genetic distance matrix and cophenetic correlation. A dendrogram was generated using the MEGA
5.0 program (Tamura et al. 2011) based on the distance matrix and the clustering method UPGMA (unweighted pair group method with arithmetic means).

\section{RESULTS}

Pollen grains of Passiflora were characterized by their morphological characteristics (shape, number and aperture type, and exine ornamentation) (Table II and Figs. 2, 3, 4). The multivariate analysis of the 18 Passiflora species allowed for the formation of three groups (Fig. 2) using the mean genetic dissimilarity (Ddg $=0.36)$ as a cutoff. The cophenetic correlations, which express the relationship between the original distances and graphically distances was $0.88(\mathrm{P}<0.0001$, 10,000 permutations). Some authors have affirmed that cophenetic correlation above 0.8 shows the adequacy of the clustering method to represent the genetic diversity among the assessed individuals (Rohlf and Fisher 1968).

The majority of Passiflora species were allocated in Group 1 (G1): P. alata, P. gibertii, $P$. edulis, P. edmundoi, P. muchronata, $P$. racemosa, $P$. setacea, $P$. galbana, P. maliformis, $P$. subrotunda, $P$. cincinnata, $P$. tenuifila and $P$. foetida (Table II and Fig. 2). All species of Group 1 belong to the subgenus Passiflora and form a homogeneous palynological complex, mainly in terms of the shape, size and type of the pollen grain openings (Table II and Figs. 2, 3, 4, 5a-i).

The palynological analysis performed using light microscopy on the accessions of Group 1 (G1) showed the presence of large pollen grains ranging from $50.2 \mu \mathrm{m}$ to $88.9 \mu \mathrm{m}$ (major axis - polar diameter), oblate spheroidal shape and 6-syncolpate aperture ( six colpos fused in pairs in the apocolpus region). The pollen grains of this group were classified as isopolar, of circular scope, with a thick heteroreticulate exine, columellate and simple muri, and with sinuous and apparent 
columelles (Table II and Figs. 3a-o, 4a-o, 5a-f). The most notable pollen characteristic that distinguishes the species of this group is the presence of bacula inserted into the lumen, with some variation in the number and height of the bacula. Some species have large lumens with many bacula inserted in their interior (Figs. 3c, 3f, 3i, 4c, 4f, 4i, 4l, 5c, 5f, $5 \mathrm{i}, 51,5 \mathrm{r}, 5 \mathrm{o}$ ), and others presented few bacula (Fig. 31, 3o, 3r, 4o). Although belonging to the subgenus Passiflora (supersection Coccinea), P. coccinea presented an exclusive shape suboblate type and was therefore allocated in Group 2 (G2), which has this characteristic as the main differential (Table II and Fig. 5g-i).

The species (P. morifolia, $P$. suberosa, and $P$. rubra) belonging to the subgenus Decaloba formed Group 3 (G3) (Table II, Fig. 2). The pollen grains of this subgenus ranged from 47.2 to $72.5 \mu \mathrm{m}$, being considered large, with distinct pollen aperture (6-colporate - P. morifolia, 6-colpate - P. suberosa and 12-colporate - P. rubra) (Fig. 5j-r). Regarding the classification of pollen grains based on the $\mathrm{PD} /$ ED ratio, these were categorized as subprolate ( $P$. suberosa and $P$. morifolia) and spheroidal prolate (P. rubra) (Table II).

Differences in the subgenus Decaloba in terms of the colpi sculpture and the number of bacula inserted in the lumen (Fig. 5j-r) were observed from the evaluation of the pollen grains in the electron microscopy. P. rubra showed a reticulated exine with sinuous muri, apparent columelles and few bacula inserted in the lumens (Fig. 5p-r). The pollen grains of $P$. morifolia also presented reticulum with sinuous muri, without apparent columelles and with many bacula inserted in the lumen (Fig. 5mo). However, in P. suberosa, the exine of the pollen grains is characterized by presence of reticulum with flat muri and absence of bacula into the lumen (Fig. 5j-1). Another pollen grain characteristic that differentiated these species was the lumen size, which was smaller in P. suberosa when compared to $P$. morifolia and P. rubra. In addition, the pollen grains of $P$. rubra and $P$. morifolia presented three mesocolpus, and $P$. suberosa presented six mesocolpus.

\section{DISCUSSION}

The pollinic characteristics are useful to differentiate and establish relationships between different species (Fazal et al. 2013, Amorim et al. 2014) because they are genetically determined and very constant and specific to each species (i.e., pollen grain size, number of apertures, aperture type and exine ornamentation) and therefore have a high taxonomic value (Mert 2010, Tangarife et al. 2011).

The pattern of clustering based on the pollinic characteristics allowed to classify the species into two subgenera, Passiflora and Decaloba, congruent with the classification of Feuillet and MacDougal (2003) and supported by phylogenetic studies using molecular markers and sequencing technique (Yockteng and Nadot 2004, Hansen et al. 2006, Mäder et al. 2010, Porter-Utley 2014, Milwardde-Azevedo et al. 2014b, Muschner et al. 2012, Krosnick et al. 2013, Ocampo and D'Eeckenbrugge 2017). These authors revealed that the Passiflora and Decaloba subgenera showed monophyletic clades.

In the present study, the subgenus Passiflora was represented by 15 species (P. alata, P. gibertii, P. edulis, $P$. edmundoi, $P$. tenuifila, $P$. galbana, $P$. muchronata, $P$. foetida, $P$. setacea, $P$. cincinnata, P. malacophylla, P. racemosa, $P$. maliformis, $P$. subrotunda and $P$. coccinea). This subgenus is characterized by leaves entire or lobed; glands on petioles, stipules, and margins of leaves; hypanthium tubular or campanulate; operculum tubular or filamentous; membranous limen, herbaceous vines or woody lianas, free serrate bracts, large colorful flowers, attract as pollinators bees, bats and hummingbirds, are diploid with $2 n$ $=18$ and self-incompatible according to described 
TABLE II

Morphopollinic characterization of 18 Passiflora species belonging to the subgenera Passiflora and Decaloba.

\begin{tabular}{|c|c|c|c|c|c|c|c|c|c|c|}
\hline \multirow{2}{*}{ Accessions } & \multirow{2}{*}{ Species } & \multicolumn{2}{|c|}{ Polar Diameter (PD) } & \multicolumn{2}{|c|}{ Equatorial Diameter (ED) } & \multirow{2}{*}{$\begin{array}{l}\mathrm{PD} / \\
\mathrm{ED}\end{array}$} & \multirow{2}{*}{ Shape } & \multirow{2}{*}{ Size } & \multirow{2}{*}{ Aperture } & \multirow{2}{*}{ Group* } \\
\hline & & $\mathrm{VF}$ & $\mathrm{x} \pm \mathrm{s}_{\mathrm{x}}$ & $\mathrm{VF}$ & $\mathrm{x} \pm \mathrm{s}_{\mathrm{x}}$ & & & & & \\
\hline BGP-004 & P. alata & $85.1-63.1$ & $71.0 \pm 8.0$ & $83.5-59.7$ & $73.3 \pm 9.2$ & 0.97 & $\begin{array}{c}\text { oblate- } \\
\text { spheroidal }\end{array}$ & Large & 6-syncolpate & G1 \\
\hline BGP-008 & P. gibertii & $80.5-64.0$ & $71.7 \pm 6.3$ & $83.4-61.8$ & $72.1 \pm 7.6$ & 0.99 & $\begin{array}{c}\text { oblate- } \\
\text { spheroidal }\end{array}$ & Large & 6-syncolpate & G1 \\
\hline BGP-038 & P. edulis & $76.4-63.4$ & $68.6 \pm 3.7$ & $77.5-63.7$ & $71.3 \pm 5.0$ & 0.98 & $\begin{array}{c}\text { oblate- } \\
\text { spheroidal }\end{array}$ & Large & 6-syncolpate & G1 \\
\hline BGP-046 & P. edmundoi & $78.6-77.6$ & $78.2 \pm 0.2$ & $83.6-82.4$ & $83.1 \pm 0.3$ & 0.94 & $\begin{array}{l}\text { oblate- } \\
\text { spheroidal }\end{array}$ & Large & 6- syncolpate & G1 \\
\hline BGP-105 & P. tenuifila & $82.1-79.5$ & $80.8 \pm 1.8$ & $82.0-78.9$ & $80.4 \pm 2.1$ & 0.94 & $\begin{array}{c}\text { oblate- } \\
\text { spheroidal }\end{array}$ & Large & 6- syncolpate & G1 \\
\hline BGP-107 & P. morifolia & $72.5-58.0$ & $62.9 \pm 3.9$ & $58.4-52.7$ & $54.6 \pm 1.3$ & 1.15 & subprolate & Large & 6-colporate & G3 \\
\hline BGP-109 & P. galbana & $88.0-87.1$ & $87.6 \pm 0.4$ & $89.8-89.5$ & $89.7 \pm 0.3$ & 0.98 & $\begin{array}{c}\text { oblate- } \\
\text { spheroidal }\end{array}$ & Large & 6-syncolpate & G1 \\
\hline BGP-114 & P. muchronata & $88.9-87.4$ & $88.1 \pm 0.3$ & $90.7-89.4$ & $90.1 \pm 0.3$ & 0.97 & $\begin{array}{c}\text { oblate- } \\
\text { spheroidal }\end{array}$ & Large & 6-syncolpate & G1 \\
\hline BGP-125 & P. rubra & $62.5-47.2$ & $52.9 \pm 5.1$ & $63.2-46.0$ & $52.4 \pm 5.4$ & 1.01 & $\begin{array}{l}\text { prolato- } \\
\text { spheroidal }\end{array}$ & Large & 12-colporate & G3 \\
\hline BGP-152 & P. suberosa & $69.1-58.2$ & $64.1 \pm 2.9$ & $66.8-51.0$ & $54.9 \pm 3.2$ & 1.16 & subprolate & Large & 12-colpate & G3 \\
\hline BGP-153 & P. foetida & $73.5-64.2$ & $67.3 \pm 2.6$ & $76.2-66.7$ & $69.7 \pm 2.9$ & 0.96 & $\begin{array}{c}\text { oblate- } \\
\text { spheroidal }\end{array}$ & Large & 6-syncolpate & G1 \\
\hline BGP-170 & $\begin{array}{c}P . \\
\text { mallacophyla }\end{array}$ & $81.7-78.4$ & $79.4 \pm 0.8$ & $82.0-78.2$ & $80.5 \pm 0.8$ & 0.99 & $\begin{array}{l}\text { oblate- } \\
\text { spheroidal }\end{array}$ & Large & 6-syncolpate & G1 \\
\hline BGP-172 & P. racemosa & $83.4-79.1$ & $81.6 \pm 0.9$ & $84.2-80.2$ & $82.8 \pm 0.9$ & 0.99 & $\begin{array}{c}\text { oblate- } \\
\text { spheroidal }\end{array}$ & Large & 6-syncolpate & G1 \\
\hline BGP-237 & P. setacea & $80.3-55.8$ & $69.0 \pm 5.8$ & $86.2-68.1$ & $75.0 \pm 5.9$ & 0.92 & $\begin{array}{c}\text { oblate- } \\
\text { spheroidal }\end{array}$ & Large & 6-syncolpate & G1 \\
\hline BGP-312 & P. cincinnata & $81.6-79.8$ & $80.6 \pm 0.5$ & $87.8-86.4$ & $87.1 \pm 0.3$ & 0.92 & $\begin{array}{c}\text { oblate- } \\
\text { spheroidal }\end{array}$ & Large & 6-syncolpate & G1 \\
\hline BGP-379 & P. maliformis & $72.0-58.1$ & $64.9 \pm 3.4$ & $72.30-57.4$ & $65.7 \pm 4.5$ & 0.99 & $\begin{array}{l}\text { oblate- } \\
\text { spheroidal }\end{array}$ & Large & 6-syncolpate & G1 \\
\hline BGP-394 & P. subrotunda & $78.5-58.1$ & $68.0 \pm 5.2$ & $80.2-63.20$ & $71.1 \pm 5.3$ & 0.96 & $\begin{array}{c}\text { oblate- } \\
\text { spheroidal }\end{array}$ & Large & 6-syncolpate & G1 \\
\hline BGP-408 & P. coccinea & $61.9-50.2$ & $55.3 \pm 3.4$ & $76.8-64.2$ & $69.6 \pm 4.6$ & 0.79 & suboblate & Large & 6-colporate & $\mathrm{G} 2$ \\
\hline
\end{tabular}




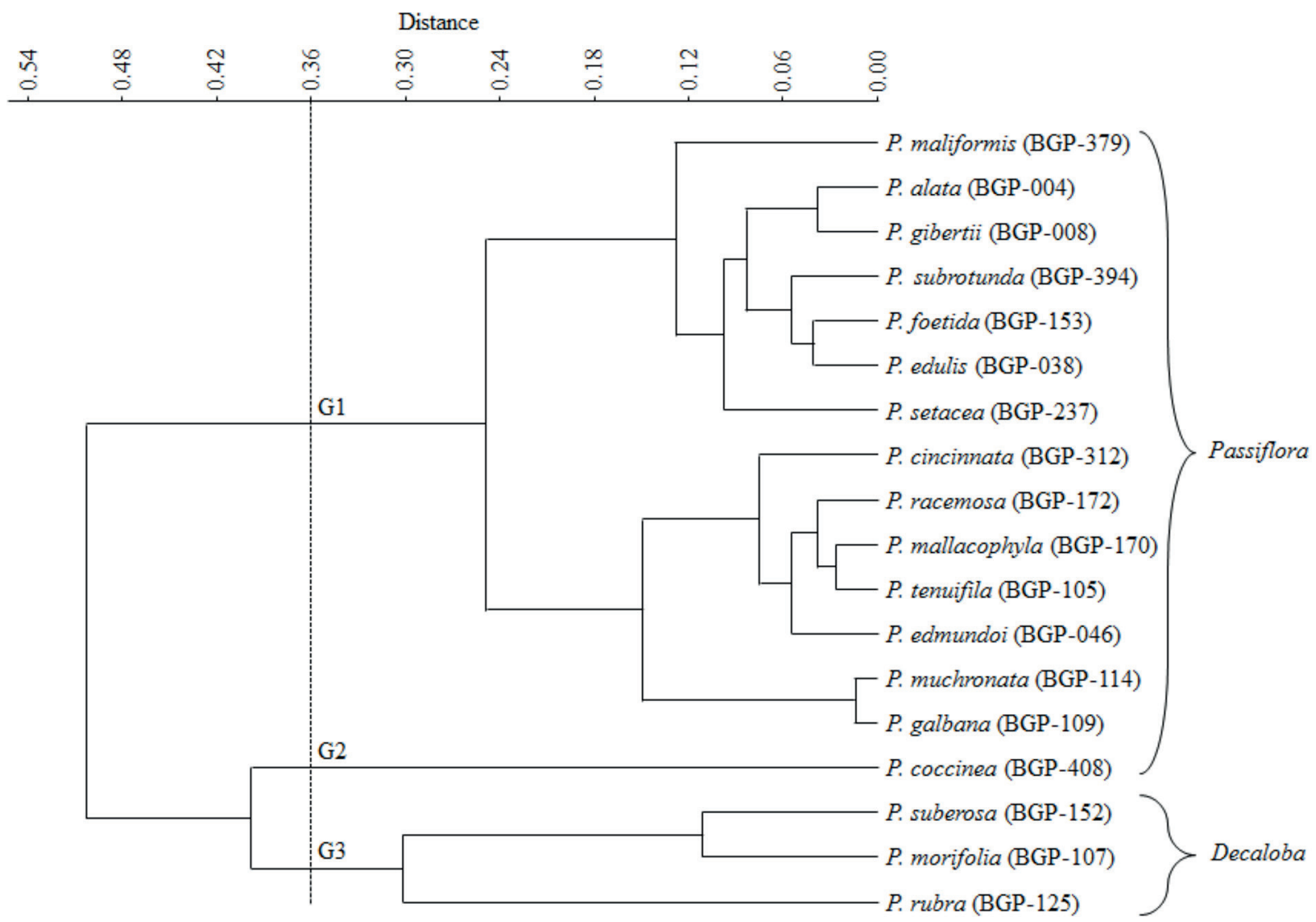

Figure 2 - Dendrogram of the 18 Passiflora species, obtained by UPGMA (unweighted pair group method using arithmetic averages) based on the Gower distance, using the qualitative and quantitative morphopollinic characteristics.

by Feuillet and MacDougal 2003, 2004, Melo and Guerra 2003, Santos et al. 2015, Ocampo and D'Eeckenbrugge 2017 (Table I). However, subgenus Decaloba is represented by P. morifolia, P. rubra and P. suberosa, characterized by the absence of ocelli on the leaf blades, by the absence of bracts, and by capsular fruits. The species present small flowers $(<4 \mathrm{~cm}$ diameter) with one or two series of corolla filaments, a folded operculum, usually white or greenish and small fruits, diploid $2 n=12,24$, according to described by Ulmer and MacDougal 2004, Milward-de-Azevedo 2014b (Table I).

In general, it was observed that the majority of the Passiflora species presented apertural membrane strongly ornamented with a large number of densified bacula inserted into the lumen. This characteristic may indicate a mechanism against dehydration, mainly during pollination, since the great majority of the analyzed species presented a relatively large apertural area. Among the species of the subgenus Passiflora, P. edulis was the one that presented pollen grains with large lumens with few bacula inserted inside (Fig. 3r), while in the species of the subgenus Decaloba, P. suberosa was the only one that did not present bacula inserted into the lumen (Fig. 31).

The pollinic characteristics based on the presence or absence of bacula are important for the taxonomic delimitation of the subgenus Decaloba in the species from southwest Brazil (Milwardde-Azevedo et al. 2004). Indeed, some pollinic 
characteristics based on the presence or absence of the bacula have been used as a palinotaxonomic resource of great importance for phylogenic studies in the Passifloraceae (Presting 1965).

Regarding the appearance of the exine surface of the Passiflora pollen grains, lipophilic substances were found between the free reticulum columelles, called pollenkitt (Fig. 3g). This substance has important functions during the pollen grain dispersion because it aids in the adhesion of the pollen grains to the body of the pollinating agent. The pollenkitt can also protect against dehydration and UV radiation damage, as well as with the pollen grain recognition system on the stigmatic surface (Pacini and Hesse 2005). Other authors also observed the presence of pollenkitt in the exine of the pollen grains of Passiflora (Souza et al. 2004, Soares et al. 2013, Silvério and Mariath 2014).

The classification of the pollen grain shape according to the $\mathrm{PD} / \mathrm{ED}$ ratio, it was observed that the majority of the species of Passiflora belonging to supersections: Laurifolia, Stipulata and Passiflora (Feuillet and MacDougal 2003) presented a PD/ED ratio above 0.90 and were therefore classified as oblate-spheroidal, with the exception of $P$. coccinea (supersection Coccinea), which presented a $\mathrm{PD} /$ ED ratio of 0.79 and a suboblate shape. This major difference could lead to the $P$. coccinea species becoming more distant from other species of the subgenus Passiflora being allocated in Group 2. Previous studies based on taxonomic progress and phylogenetic analyses using molecular markers particularly over the last 11 years by Muschner et al. (2003), Yockteng and Nadot (2004), and Hansen et al. (2006) did not support the classifications into supersections, sections, and series.

In contrast, in the subgenus Decaloba represented by P. morifolia, P. rubra and P. suberosa belonging to two supersections (Bryonioides and Decaloba) according to classification proposed by Feuillet and MacDougal (2003) presented a subprolate pollen grain shape was observed for $P$. morifolia and $P$. suberosa, while a prolato-spheroidal shape of the pollen grain was observed in P. rubra, similar to the results described by Milward-deAzevedo et al. (2010). Some authors have affirmed that the oblate-spheroidal, prolate-spheroidal and spheroidal shapes confer the Passifloreaceae with one of their main palynological characteristics and may help in the taxonomic classification of this group (Mezzonato-Pires et al. 2015b).

Other descriptors of high value diagnostic for studies taxonomic in Passiflora are those related to the pollen grain morphology and the pollen aperture (Dettke et al. 2009, Mezzonato-Pires 2015a,b). The wide morphological diversity of the Passifloraceae has enabled the creation of different types of pollen. Presting (1965) identified typical pollen grains for the species of the Passifloraceae using the reticulum pattern (lumen diameter and presence or absence of bacula) and exine thickness as criteria. On the other hand, Araújo and Santos (2004) chose pollen types based on the operculum variations (elliptic and pontoperculum operculum) and sizes of the reticles lumens. In the present study, the pollen types were typified based on the apertural pattern, shape of the pollen grains and the muri characteristics with the presence or absence of bacula in the lumen.

However, previous studies have shown contradictory results due to the complexity of the pollen grains of the Passifloraceae species, especially in relation to the pollen grain size and the type and number of pollen grains. The pollen aperture in $P$. alata was described in the literature as being 6-colpate (Dettke and Santos 2009) or 6-syncolpate (Araújo and Santos 2004, Evaldt et al. 2011). For P. edulis, Tangarife et al. (2011) classified the pollen aperture as 6-colporoid, while Dettke and Santos (2009) described it as 6-colpate. Recently, Menzzonato-Pires et al. (2015b) classified the pollen aperture of $P$. alata, $P$. racemosa, $P$. edulis, P. foetida and P. setacea as 6-syncolpate and that of $P$. mucronata as 6-colpate. The results 

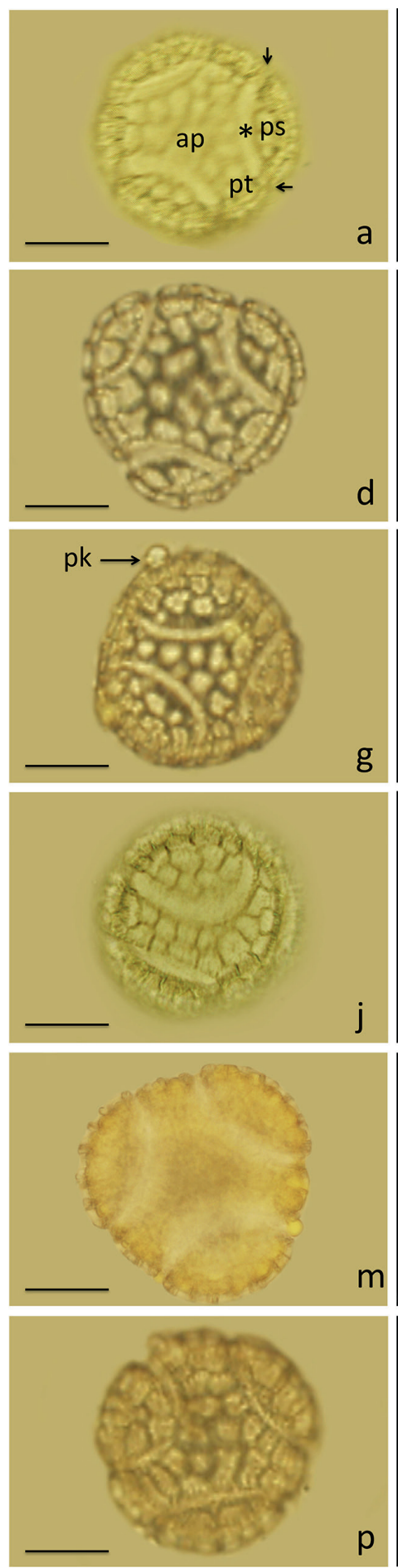
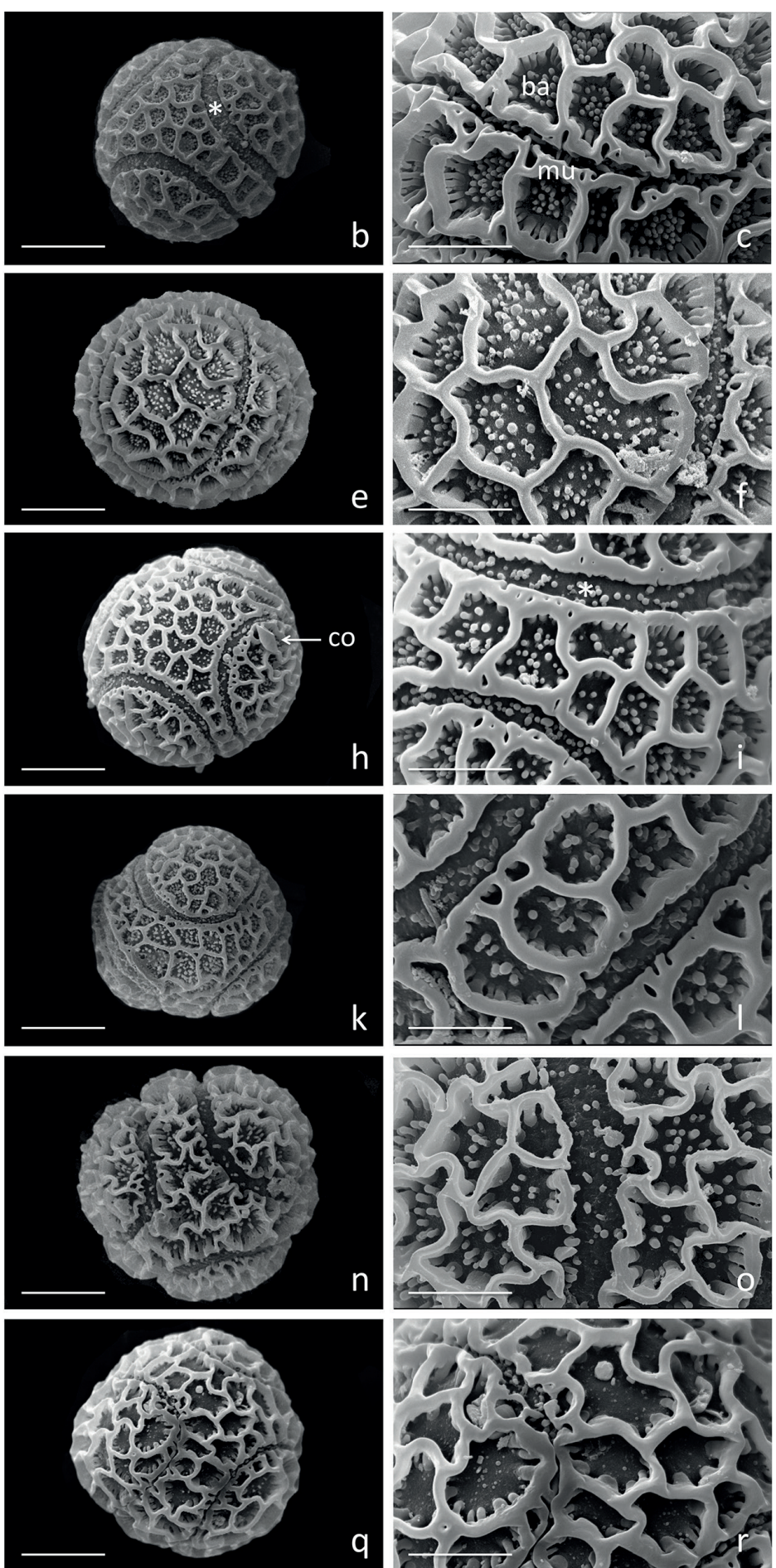

Figure 3 - Pollen grains of Passiflora using a light microscope (LM) and a scanning electron microscope (SEM). a-c) P. maliformis (BGP-379); d-f) P. alata (BGP-004); g-i) P. gibertii (BGP-008); j-l) P. subrotunda (BGP-394); m-o) P. foetida (BGP-153); p-r) P. edulis (BGP-038); a, d, g, j, m, p) LM overview; b, e, h, k, n, q) SEM overview; c, f, i, 1, o, r) details of the exine and colpi using an SEM. ap: apocolpus; ba: bacula; co: calcium oxalate crystals; mu: muri; pk: pollenkitt; ps: pseudoperculum; pt: pontoperculum; arrow: apertures; *fusion of the apertures within the apocolpus. Bars: a, b, d, e, g, h, j, k, m, n, p, q = $20 \mu \mathrm{m} ; \mathrm{c}, \mathrm{f}, \mathrm{i}, \mathrm{l}, \mathrm{o}, \mathrm{r}=10 \mu \mathrm{m}$. 

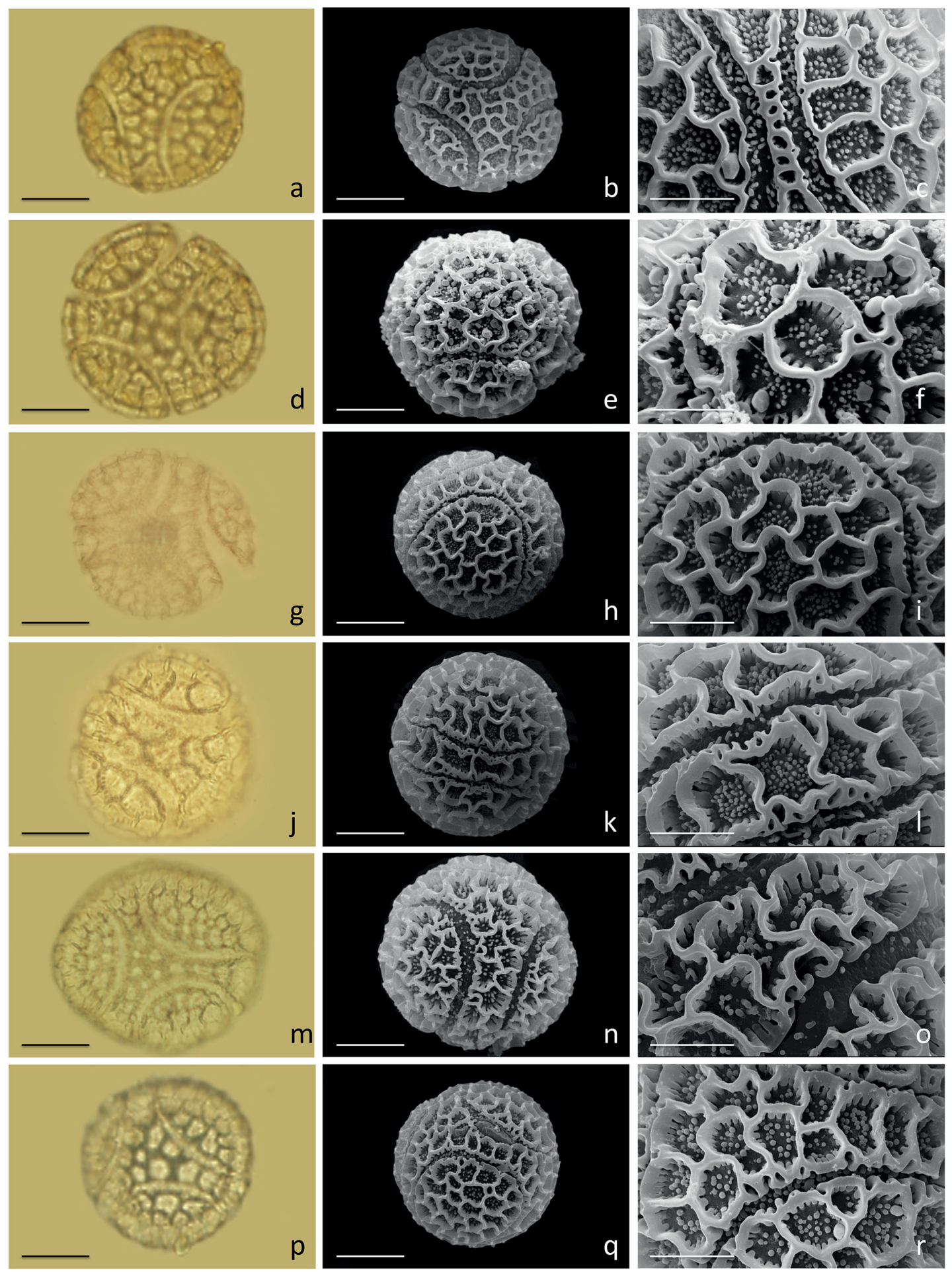

Figure 4 - Pollen grains of Passiflora using a light microscope (LM) and a scanning electron microscope (SEM); a-c) P. setacea (BGP-237); d-f) P. cincinnata (BGP-312); g-i) P. racemosa (BGP-172); j-l) P. mallacophyla (BGP170); m-o) P. tenuifila (BGP-105) p-r); P. edmundoi (BGP-046); a, d, g, j, m, p) LM overview; b, e, h, k, n, q) SEM overview; c, f, i, l, o, r) details of the exine and colpi using an SEM. Bars: a, b, d, e, g, h, j, k, m, n, p, q = 20 $\mu \mathrm{m} ; \mathrm{c}, \mathrm{f}, \mathrm{i}, 1, \mathrm{o}, \mathrm{r}=10 \mu \mathrm{m}$. 

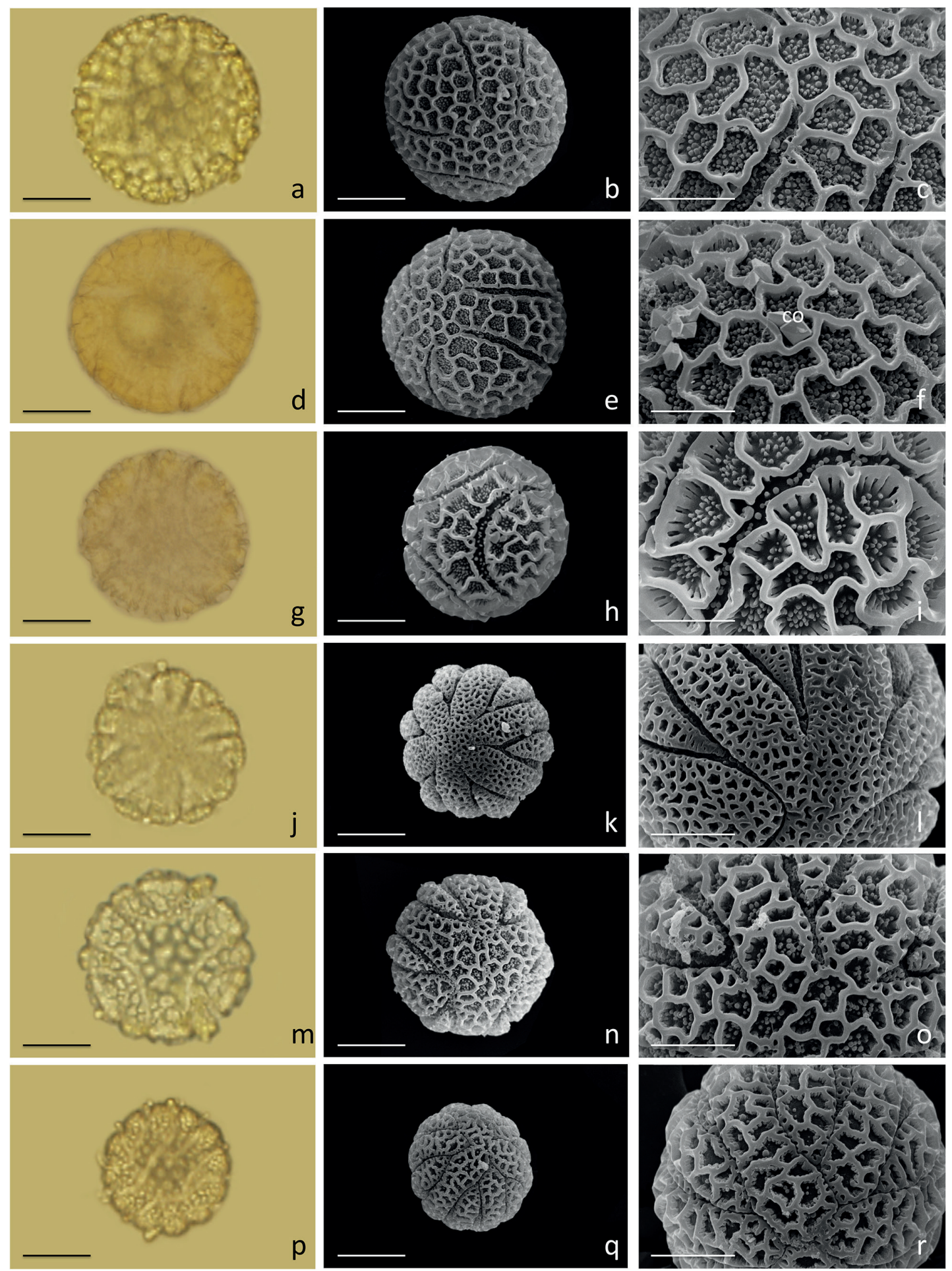

Figure 5 - Pollen grains of Passiflora using a light microscope (LM) and a scanning electron microscope (SEM); a-c) P. muchronata (BGP-114); d-f) P. galbana (BGP-109) g-i); P. coccinea (BGP-408); j-l) P. suberosa (BGP152); m-o) P. morifolia (BGP-107); p-r) P. rubra (BGP-125); a, d, g, j, m, p) LM overview; b, e, h, k, n, q) SEM overview; c, f, i, l, o, r) details of the exine and colpi using an SEM. co: calcium oxalate crystals. Bars: a, b, d, e, $\mathrm{g}, \mathrm{h}, \mathrm{j}, \mathrm{k}, \mathrm{m}, \mathrm{n}, \mathrm{p}, \mathrm{q}=20 \mu \mathrm{m} ; \mathrm{c}, \mathrm{f}, \mathrm{i}, \mathrm{l}, \mathrm{o}, \mathrm{r}=10 \mu \mathrm{m}$. 
related to the type of ornamentation and pollen aperture found by the authors were partially similar to those obtained in the present study, except for P. mucronata, with 6-syncolpate aperture. Studies carried out by other authors have shown that there is some divergence in the pollen morphology in the majority of Passiflora species, with differences in the pollen grain number, type of pollen aperture and nomenclatures adopted for the pollen grain structures. This divergence likely occurs because the studies of pollen characterization of Passiflora deal with descriptions based mainly on the external aspect of the exine, which contributes to several interpretations (Detcke 2009, Evaldt et al. 2011).

For the characteristics shape, number and aperture type of the pollen grains of the subgenus Decaloba, there is a consensus in the pollen descriptions for P. rubra (Milward-de-Azevedo et al. 2010, 2014a, Amorim et al. 2014). However, this was not observed for the other two species of the subgenus Decaloba, P. morifolia and $P$. suberosa, which had pollen grains classified as 6-colporate (Dettke and Santos 2009), 12-colpate (Amela García et al. 2002, Milward-de-Azevedo et al. 2004), oblate (Silvério and Mariath 2014), prolate-spheroidal (Milward-de-Azevedo et al. 2004) and subprolate (Milward-de-Azevedo et al. 2010). The results reported by these authors were similar to those observed in the present work for P. suberosa and P. morifolia in terms of the pollen grains subprolate format and the 12-colporate pollen opening.

However, our results demonstrate relative congruence with most of the taxonomic affinities related to the subgenera Passiflora studied and show that the classification of the Passiflora species can be carried out based on morphological characteristics of the pollen grains, thus identifying morphopollinic patterns (i.e., pollen grain shape, pollen apertures and ornamentation of the exine), which can contribute to the taxonomy of this genus.

Most of the species studied belong to the subgenus Passiflora $(2 \mathrm{n}=18)$ area presents self-incompatible, while those of the subgenus Decaloba are self-compatible $(2 \mathrm{n}=6)$ (Melo et al. 2016). Although there is no chromosome homology between these subgenera, many interspecific hybrids of Passiflora have been successfully obtained, because in many cases the barriers of interspecific incompatibility are relatively fragile (Meletti et al. 2005, Soares et al. 2015). Thus, the Passiflora species used in the present work have great potential in interspecific hybridization programs with the purpose of introgression of resistance genes in yellow passion fruit (P. edulis), which is the main commercial species in Brazil. Among the interesting characteristics present in some evaluated species are: resistance to foliar diseases (Santos et al. 2015, Jesus et al. 2016, Freitas et al. 2016a) and soil (Freitas et al. 2016b) and the presence of self-compatibility which can increase productivity and decrease variation in fruit size among plants in commercial plantations. In addition, interspecific hybrids among the wild species studied have shown ornamental potential (Bugallo et al. 2011, Santos et al. 2012, 2014, Ocampo et al. 2016, Melo et al. 2016, Coelho et al. 2016).

It is interesting to note that although the pollen morphology analysis may be useful in taxonomic studies of the Passiflora genus, it should only be considered an additional tool for species classification to increase our understanding of the systematics of the genus, for re-evaluating the circumscriptions and arrangements of the infrageneric categories currently established, and for better understanding the phylogenetic lineages of the Passiflora. Futher studies should be carried out under the light transmission electron microscopy and ontogeny of the structures that compose the pollen grain sporoderm of the Passiflora, enabling better understanding of the exine ornamentation and probably highlighting other traits that may be useful to the classification of the taxa. 


\section{CONCLUSIONS}

The morphology of Passifloraceae pollen grains can be used as a morphological descriptor to establish the taxonomy and phylogenetic relationships of the species of this family. However, future studies involving transmission electron microscopy will be necessary to enable better understanding of the exine ornamentation, probably highlighting other palynological characteristics that can be used in the delimitation of the taxa.

\section{ACKNOWLEDGMENTS}

The authors are grateful to the Fundação de Amparo à Pesquisa do Estado da Bahia (FAPESB) and the Conselho Nacional de Desenvolvimento Científico e Tecnológico (CNPq) for financial support for research and fellowship (DCR0013/2015) granted to the first author, and the Coordenação de Aperfeiçoamento de Pessoal de Nível Superior (CAPES-PROCAD - 2013 and CAPES/ EMBRAPA) and the NAP/MEPA - ESALQ/USP (Centre for the Support of Electron Microscopy Research Applied to Agriculture) by the use of scanning electron microscopy. We also thank the curator and staff of the herbarium (HURB Universidade Federal do Recôncavo da Bahia).

\section{REFERENCES}

AMELA GARCIIA MTA, GALAATI BG AND ANTON AM. 2002. Microsporogenesis, microgametogenesis and pollen morphology of Passiflora spp. (Passifloraceae). Bot J Linn Soc 139: 383-394.

AMORIM JS, SOUZA MM, VIANA AJC, CORRÊA RX, ARAÚJO IS AND AHNERT D. 2014. Cytogenetic, molecular and morphological characterization of Passiflora capsularis L. and Passiflora rubra L. Plant Syst Evol 300: 1147-1162.

ARAÚJO RCM AND SANTOS FAR. 2004. Palinologia de espécies do gênero Passiflora L. (Passifloraceae) da Chapada Diamantina, Bahia, Brasil. Sitientibus 4: 37-42.

BERNACCI LC, CERVI AC, MILWARD-DE-AZEVEDO MA, NUNES TS, IMIG DC AND MEZZONATO AC. 2015. Passifloraceae in Lista de Espécies da Flora do Brasil Jardim Botânico do Rio de Janeiro, 28 March,
2015 Available at: http://floradobrasil.jbrj.gov.br/jabot/ floradobrasil/FB182.

BUGALLO V, CARDONE S, PANNUNZIO M AND FACCIUTO G. 2011. Breeding advances in Passiflora spp. (Passionflower) native to Argentina. Floric Ornam Biotech 5: 23-34.

COELHO MSE, BORTOLETI KCA, ARAÚJO FP AND MELO NF. 2016. Cytogenetic characterization of the Passiflora edulis Sims x Passiflora cincinnata Mast. interspecific hybrid and its parentes. Euphytica 210: 93104.

DETTKE GA AND SANTOS RP. 2009. Tipos de aberturas dos grãos de pólen de espécies de Passiflora L. (Passifloraceae). Acta Bot Bras 23: 1119-1128.

ESCOBAR LK. 1988. Monografía No 10. Passifloraceae. Passiflora. Subgéneros: Tacsonia, Rathea, Manicata and Distephana. Universidad Nacional de Colombia, Bogotá D.E.

ESCOBAR LK. 1989. A new subgenus and five new species in Passiflora (Passifloraceae) from South America. Ann Missouri Bot Gard 76: 877-885.

ESCOBAR LK. 1994. Two new species and a key to Passiflora subg. Astrophea. Syst Bot 19: 203-210.

EVALDT ACP, BAUERMANN SG, CANCELLI RR, ACIOLI M AND NEVES PCP. 2011. Morfologia polínica de Passifloraceae Juss ex Kunth no Rio Grande do Sul, Brasil. Rev Bras Biocienc 9: 75-87.

FAZAL H, AHMAD NAND ABBASI BH. 2013. Identification, characterization, and palynology of high-valued medicinal plants. Sci World J 2013: 1-9.

FEUILLETCAND MACDOUGAL J. 2003. Anew infrageneric classification of Passiflora L. (Passifloraceae). Passiflora 13: $34-38$.

FEUILLETCAND MACDOUGAL J. 2004. Anew infrageneric classification of Passiflora L. (Passifloraceae). Passiflora 13: $37-38$

FREITAS JCO, VIANA AP, SANTOS EA, PAIVA CL, SILVA FHL, AMARAL JR AT, SOUZA MM AND DIAS VM. 2016b. Resistance to Fusarium solani and characterization of hybrids from the cross between $P$. mucronata and $P$. edulis. Euphytica 208: 493-507.

FREITAS JCO, VIANA AP, SANTOS EA, PAIVA CL, SILVA FHL AND SOUZA MM. 2016a. Sour passion fruit breeding: Strategy applied to individual selection insegregating population of Passiflora resistant to Cowpea aphid-born mosaic virus (CABMV). Sci Hort 211: 241247.

FRITZSCHE J. 1837. Über den Pollen. Mem Sav Etrang Acad St Petersburg 3: 649-672.

GABARAYEVA N, GRIGORJEVA V AND KOSENKO Y. 2013. Exine development in Passiflora racemosa Brot: post-tetrad period Overlooked aspects of development. Plant Syst Evol 299: 1037-1055. 
GOWER JC. 1971. A general coefficient of similarity and some of its properties, Biome 27: 857-874.

HANSEN AK, LAWRENCE G, SIMPSON BB, DOWNIE SR, STEPHEN R, CERVI AC AND JANSEN RK. 2006. Phylogenetic relationships and chromosome number evolution in Passiflora. Syst Bot 31: 138-150.

HESSE M, HALBRITTER H, ZETTER R, WEBER M, BUCHNER R, FROSCH-RADIVO A AND ULRICH S. 2009. Pollen terminology - An illustrated handbook. Vienna: Springer, $266 \mathrm{p}$.

JESUS ON, SOARES TL, OLIVEIRA EJ, SANTOS TCP, FARIAS DH, BRUCKNER CH AND NOVAES QS. 2016. Dissimilarity based on morphological characterization and evaluation of pollen viability and in vitro germination in Passiflora hybrids and backcrosses. Acta Hort 29: 401408.

JUDD WS, CAMPBELL CS, KELLOGG EA, STEVENS PF AND DONOGHUE MJ. 2007. Plant systematics: a phylogenetic approach. Sunderland: Massachusetts, $677 \mathrm{p}$.

KARNOVSKY MJ. 1965. A formaldehyde-glutaraldehyde fixative in high osmolality for use in electron microscopy. J Cell Biol 27: 137-138A.

KILLIP EP. 1938. The American species of Passifloraceae. Publications Field Museum of Natural History, Bot Series 19: 1-613.

KROSNICK SE, PORTER-UTLEY K, JORGENSEN P AND MCDADE L. 2013. New Insights into the Evolution of Passiflora subgenus Decaloba (Passifloraceae): Phylogenetic Relationships and Morphological Synapomorphies. Syst Bot 38: 692-713.

KROSNICK S, FORD AJ AND FREUDENSTEIN JV. 2009. Taxonomic revision of Passiflora subgenus Tetrapathea including the Monotypic Genera Hollrungia and Tetrapathea (Passifloraceae) and a New Species of Passiflora. Syst Bot 34: 375-385.

MACDOUGAL JM. 1994. Revision of Passiflora section Decaloba, Pseudodysosmia (Passifloraceae). Syst Bot Monogr 14: 1-46.

MÄDER G, ZAMBERLAN PM, FAGUNDES NJR, MAGNUS T, SALZANO FM, BONATTO, SL, AND FREITAS LB. 2010.The use and limits of ITS data in the analysis of intraspecific variation in Passiflora L. (Passifloraceae). Genet Mol Biol 33: 99-108.

MELETTI LMM, SOARES-SCOTT MD, BERNACCI LC AND PASSOS IRS. 2005. Melhoramento genético do maracujá: passado e futuro. In: Faleiro FG, Junqueira NTV and Braga MF. (Eds), Maracujá: germoplasma e melhoramentogenético. Embrapa Cerrados, Planaltina, p. 55-78.

MELO CAF, SOUZA MM, VIANA AP, SANTOS EA, SOUZA VO AND CORRÊA RX. 2016. Morphological characterization and genetic parameter estimation in backcrossed progenies of Passiflora L. for ornamental use.
Sci Hort 212: 91-103.

MELO F, CERVI A AND GUERRA M. 2001. Karyology and cytotaxonomy of the genus Passiflora L. (Passifloraceae). Plant Syst Evol 226: 69-84.

MELO NF AND GUERRA M. 2003. Variability of the 5S and rDNA sites in Passiflora L. with species with distinct base chromosome numbers. Ann Bot 92: 309-316.

MERT C. 2010. Anther and pollen morphology and anatomy in walnut (Juglans regia L.) Hortscience 45: 757-760.

MEZZONATO-PIRES AC, MENDONÇA CBF AND GONÇALVES-ESTEVES V. 2015b. Pollen morphology of selected species of Passiflora L. (Passifloraceae) from the Atlantic Forest. Acta Bot Bras 29: 391-399.

MEZZONATO-PIRES AC, MILWARD-DE-AZEVEDO MA, MENDONÇA CBF AND GONÇALVES-ESTEVES V. 2015a. Pollen morphology and detailed sexine of Passiflora subgenus Astrophea (Passifloraceae). Plant Syst Evol 301: 2189-2202.

MILWARD-DE-AZEVEDO MA, FREITAS LB AND KINOSHITA LS. 2014b. Taxonomy and evolutionary relationships of Passiflora subg Decaloba supersect Decaloba sect Xerogona (Passifloraceae): contributions of palynological, morphological and molecular studies. Acta Bot Bras 28: 301-308.

MILWARD-DE-AZEVEDO MA, GONÇALVES-ESTEVES V AND BAUMGRATZ JF. 2004. Palinotaxonomia das espécies de Passiflora L. subg Decaloba (DC) Rchb (Passifloraceae) no sudeste do Brasil. Rev Bras Bot 27: 655-665.

MILWARD-DE-AZEVEDO MA, SOUZA FC, BAUMGRATZ JFA AND ESTEVES VG. 2010. Palinotaxonomia de Passiflora L subg Decaloba (D.C.) Rchb (Passifloraceae) no Brasil. Acta Bot Bras 24: 133-145.

MILWARD-DE-AZEVEDO MA, SOUZA, FC, GONÇALVES-ESTEVES V AND KINOSHITA LS. 2014a. Palinotaxonomy of Passiflora section Xerogona (Passifloraceae). Phytotaxa 159: 1-10.

MOHL H. 1834. Beiträge zur Anatomie und Physiologie der Gewächse: Über den Bau und die Formen der Pollenkörner Bern, Chr Fischer und Comp, 120 p.

MUSCHNER V, LORENZ-LEMKE A, CERVI AC, BONATTO S, SOUZA-CHIES T, SALZANO F AND FREITAS L. 2003. A first molecular phylogenetic analysis of Passiflora (Passifloraceae). Amer J Bot 90: 1229-1238.

MUSCHNER V, ZAMBERLAN PM, BONATTO S, AND FREITAS L. 2012. Phylogeny, biogeography and divergence times in Passiflora (Passifloraceae). Genet Mol Biol 35: 1036-1043.

OCAMPO J, ARIAS JC AND URREA R. 2016. Interspecific hybridization between cultivated and wild species of genus Passiflora L. Euphytica 209: 395-408.

OCAMPO JP, AND D'EECKENBRUGGE GC. 2017. Morphological characterization in the genus Passiflora L. 
an approach to understanding its complex variability. Plant Syst Evol 303: 531-558.

PACINI E AND HESSE M. 2005. Pollenkitt - its composition, forms and functions. Flora 200: 399-415.

PORTER-UTLEY K. 2014. A revision of Passiflora L subgenus Decaloba (DC) Rchb supersection Cieca (Medik) J M MacDougal \& Feuillet (Passifloraceae). PhytoKeys 43: $1-224$.

PRESTING D. 1965. Zur morphologie der Pollenkorner der Passifloraceen Pollen Spores 7: 193-247.

PUNT W, HOEN PP, BLACKMORE S, NILSSON S, AND LE THOMAS A. 2007. Glossary of pollen and spore terminology. Rev Paleobot Palynol 143: 1-81.

RASBAND WS. 1997-2016. ImageJ, U S National Institutes of Health, Bethesda, Maryland, USA, http://imagej.nih. gov/ij.

RAYNAL A AND RAYNAL J. 1979. Une technique de préparation des grains de pollen fragiles. Adansonia 2: 7779.

R DEVELOPMENT CORE TEAM. 2015. A language and environment for statistical computing, Vienna: R Foundation for Statistical Computing.

ROHLF FJ AND FISHER DR. 1968. Test for hierarchical structure in random data sets. Syst Zool 17: 407-412.

SANTOS EA, SOUZA MM, ABREU PP, CONCEIÇÃO LDHCS, ARAÚJO IS, VIANA AP AND ALMEIDA AAF. 2012. Confirmation and characterization of interspecific hybrids of Passiflora L. (Passifloraceae) for ornamental use. Euphytica 184: 389-399.

SANTOS EA, VIANA AP, FREITAS JCO, SOUZA MM AND PAIVA CL. 2014. Phenotyping of Passiflora edulis, P. setacea, and their hybrids by a multivariate approach. Genet Mol Res 13: 9828-9845.

SANTOS EA, VIANA AP, FREITAS JCO, SILVA FHL, RODRIGUES R AND EIRAS M. 2015. Resistance to Cowpea aphid-borne mosaic virus in species and hybrids of Passiflora: advances for the control of the passion fruit woodiness disease in Brazil. Eur J Plant Pathol 143: 85-98.
SILVA VJD, RIBEIRO EM, LUIZI-PONZO AP AND FARIA APG. 2016. Ultrastructure and pollen morphology of Bromeliaceae species from the Atlantic Rainforest in Southeastern Brazil. An Acad Bras Cienc 88: 439-449.

SILVÉRIO A AND MARIATH JEA. 2014. Comparative structure of the pollen in species of Passiflora: insights from the pollen wall and cytoplasm contents. Plant Syst Evol 300: 347-358.

SOARES TL, JESUS ON, SOUZA EH, AND OLIVEIRA EJ. 2015. Reproductive biology and pollen-pistil interactions in Passiflora species with ornamental potential. Sci Hort 197: 339-349.

SOARES TL, JESUS ON, SOUZA EH, SANTOS-SEREJO JA AND OLIVEIRA EJ. 2013. Morphology and viability of pollen grains from passion fruit species (Passiflora spp) Acta Bot Bras 27: 779-787.

SOKAL RR AND ROHLF FJ. 1962. The comparison of dendrograms by objective methods Taxon 11: 33-40.

SOUZA MM, PEREIRA TNS, VIANA AP, SILVA LC AND SUDRÉ CP. 2004. Pollen viability and fertility in wild and cultivated Passiflora species (Passifloraceae). Beitr Biol Pflanzen 73: 1-18.

TAMURA K, DUDLEY J, NEI M AND KUMAR S. 2011. MEGA5: Molecular Evolutionary Genetics Analysis Using Maximum Likelihood, Evolutionary Distance, and Maximum Parsimony Methods. Mol Biol Evol 28: 27312739.

TANGARIFE MMM, CAETANO CM AND CHÁVEZSÉRVIA JL. 2011. Palinology of some species of Passifloraceae Neotropical: Palynology of some Passifloraceae. Rev Investig Univ Quíndio 22: 141-149.

ULMER T AND MACDOUGAL JM. 2004. Passiflora: passionflowers of the world. Timber Press Portland, Oregon.

YOCKTENG R AND NADOT S. 2004. Phylogenetic relationships among Passiflora species based on the glutamine synthetase nuclear gene expressed in chloroplast (ncpGS). Molec Phylogen Evol 31: 379-396. 